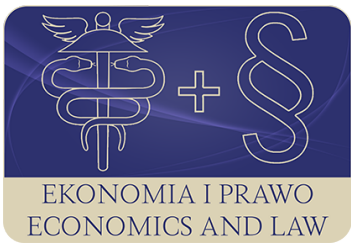

EKONOMIA I PRAWO. ECONOMICS AND LAW

Volume 18, Issue 4, December 2019

p-ISSN 1898-2255, e-ISSN 2392-1625

www.economicsandlaw.pl

EKONOMIA I PRAWO

ORIGINAL ARTICLE

received 25.04.2019; revised 20.12.2019; accepted 31.12.2019

Citation: Kilanowski, M. (2019). Human rights should be our business. Ekonomia i Prawo. Economics and Law, 18(4): 459-473.

doi:10.12775/EiP.2019.030.

\title{
Human rights should be our business
}

\section{MARCIN KILANOWSKI}

Nicolaus Copernicus University in Toruń, Faculty of Law and Administration, Department of Theory of Law and the State, ul. Władysława Bojarskiego 3, 87-100 Toruń, Poland

曰markil@umk.pl

(D) orcid.org/0000-0001-7105-0062

\begin{abstract}
Motivation: Until today, businesses have very often not seen the need to focus on the protection of human rights when conducting business activities. Recent cases involving BP, Royal Dutch Shell, Volkswagen show that even the most well-known corporations violate human rights. After the analysis of several pertinent legal texts, I will present my arguments as to why businesses should protect human rights even though it is difficult to present a universal basis for these rights.

Aim: The business world is often critical of its obligation to protect human rights and its core value which is human dignity. There are however difficulties in presenting arguments that can frame how we should understand the nature of human dignity. This article aims to present these difficulties, which can be understood not only as a challenge but also as an opportunity to rethink the reasons why businesses should adjust their conduct in a way that does not violate human rights.

Results: The analysis of the legal and philosophical literature as well as international texts and court rulings shows that it is difficult to present a clear answer regarding the meaning of the notion of human dignity as the basis for the protection of human rights. Such a difficulty can be perceived however as an opportunity to apply a pragmatic approach and to create an open dialogue about the scope of human rights protection of which businesses should be a part. It should not only be in the interest of states to protect human rights, who are involved in creating treaties and in their implementation, but also in the interest of business entities. Human rights are our business and they should also be the business of businesses, taking responsibility for the human rights violations caused by their operations. These violations can be prevented by applying a pragmatic approach,

thanks to communication with those willing to present critical views, and by resting the judgements of businesses on their ongoing critical assessment of their activities, taking
\end{abstract}


under considerations not only profit margins but also the other human beings impacted by their operations.

Keywords: human rights; human dignity; international law; business entities; business conduct; pragmatic approach

JEL: Z10; Z13; Z19

\section{Introduction: business and human rights}

The Guiding principles on business and human rights marks a very important step in making clear that human rights should be respected by businesses throughout their entire operation, not only 'locally', within the Western nation-state context, but more globally, as business activities today have no borders (United Nations, 2011). But how can we convince everyone to respect human rights, not only states but also small businesses and large corporations, in these times of clashing civilizations and in light of the emergence of multicultural societies, where we witness different views on what is of primary importance and what should be the basis for our ethical conduct? ? Today, as never before, we are exposed to different cultures at home and abroad with different understandings of the world and different values that are shared by their members ${ }^{2}$. In such circumstances, it is difficult to defend human rights, especially as a universal set of norms that should be respected by all ${ }^{3}$. Such a difficulty is not new ${ }^{4}$. To overcome it the drafters of the human rights treaties in the 20th century often referred to the notion of inherent human dignity, which should constitute the basis for the respect of human rights. ${ }^{5}$ With reference to human dignity as the basis on which we should rest our respect for other human beings (respect their rights), when doing business, another question arises: how should we understand human dignity? In order to answer these questions, I will first refer to pertinent aspects of the legal and philosophical literature, and secondly will analyze some international conventions and international treaties in order to finally frame my analysis of court rulings. I will then present a set of conclusions for businesses and for their conduct that can be drawn on the basis of the aforementioned analysis.

${ }^{1}$ On the clash of civilizations, see Huntington (2011). On the emergence of multicultural societies and the new problems they create please, see Kymlicka (2010). On the multiple dilemmas that we face in the rapidly developing world and what should be our ethical stance, see Sandel (2013).

2 On different competing values, see Pearce \& Littlejohn (1997).

3 On difficulties with defending universal human rights, see Turner (2006).

${ }^{4}$ On the history of the development of the human rights regime, see Moyn (2010).

5 Reference to human dignity becomes crucial in the 20th century: Habermas (2010, pp. 465-66). 


\section{Difficulties in understanding human dignity}

If we were to peruse the legal and philosophical literature on human dignity, we would see that many scholars and legal experts have difficulty presenting a case for how we should understand it and what its status should be $\mathrm{e}^{6}$. In light of these difficulties, we can follow the words of Neuman (2000, p. 250): 'despite the importance of these disagreements over the source, character, and consequences of intrinsic human worth, all accounts of human dignity share certain common features that distinguish them from other accounts of the relationship between the individual and the state, and at least the Western accounts of human dignity represent variants of a common historical tradition'. This account accurately represents the current state of our knowledge. So how have others tried to deal with the difficult task of understanding the notion of human dignity? When reading the above, however, we might ask ourselves what these common features are that Neuman is referring to? What are the 'all accounts' that he mentions? He does not say more, except for adding that 'at least' the Western account of human dignity can be an example that there is some common feature, but still adds that this Western account represents 'variants' of a common historical tradition. It is most likely the case that what he has in mind is that these common features can be found in our common history and common traditions, even though they are so diverse. However, one might become skeptical about this common feature when one looks closely at what the Western 'tradition' stands for across its history. Is there a tradition of recognizing human dignity that unites the different ways in which our Western history developed, except for the one that we can find among philosophical texts, even though this can also be questioned? In the words of Neuman (2000, p. 250), one can point out to 'totalitarian ideologies', 'organic theories of nationalism that submerge the individual', 'authoritarian political doctrines that condemn human nature as degraded by sin', 'racist doctrines of biological inferiority' and 'white aristocratic doctrines of natural hierarchy'. They also form a part of the Western tradition, too, albeit for some a shameful part.

In light of such a historical background, it is difficult to be satisfied with the claim that some portion of our tradition is referring to the notion of human dignity while other parts are not, or are only referring to the human dignity of some people and not of others (Neuman, 2000, p. 270). We should always

6 See for example Dupré (2015), Gilabert (2018), McCrudden (2012) or Waldron (2012).

7 Others try to present a metaphysical justification for human dignity. This approach does not bring us any closer to resolving the problem of establishing a widespread recognition of the need to respect human dignity and to respect human rights because there are different competing metaphysical justifications of our values. For more on this subject, see Broome (2000) or Chang (1997). Moreover, there are those that present a realistic account of what should matter for us, which are far from giving any sort of metaphysical explanation. See for example Kennedy (2004). 
remember that our Western tradition is formed by convictions about the worth of every individual human, as well as by Nazi gas chambers, concentration camps in the Balkans and modern forms of slavery in Western countries, often present within the walls of businesses, which do it against the law at home, but enjoy the 'freedom' to do so when operating abroad ${ }^{8}$. Keeping in mind these diverse experiences of humankind, which are characteristic not only for the Western world but also for its other corners, many present lengthy analyses which refer to human dignity as a context-dependent value - dependent on social, political or economic circumstances ${ }^{9}$. The awareness of context as well as the ambiguity of our history and of our reality does not allow them to state that there is some clear human progress that leads to a better understanding of human dignity and respect for human rights ${ }^{10}$. Among them is Kennedy (2004, p. 25), who criticizes talk of universal human dignity, universal human rights and those based on a system of human rights protection on the common understanding of the notion of human dignity. He goes on to criticize the vagueness of norms, which together with other features of the human rights movement, may even lead to the creation of more injustice than there was in the first place. He says: 'the vague and conflicting norms, their uncertain status, the broad justifications and excuses, the lack of enforcement, the attention to the problems which are peripheral to a broad conceived program of social justice - all these may, in some contexts, place the human rights movement in the uncomfortable position of legitimating more injustice than it eliminates'.

\section{Analysis of legal texts}

We might be worried by some of the conclusions which we find in the legal and philosophical literature that questions the possibility of presenting a common understanding of the notion of human dignity, as well as those that propose ceasing any efforts to search for what unites us in the variety of experiences and plurality of worldviews (Rorty, 1996). If that were the case, then we could argue that it is impossible to convince businesses to see their own responsibility in respecting human rights when running their organizations, because we cannot find agreement on the jurisdiction of human rights and human dignity. In return we may hear that businesses from the very outset focus on profit for their shareholders, that they adjust their business conduct to the social and market circumstances to maximize profit and that they should not be obliged to focus on human rights in light of the difficulties they would face within their field. One can argue, however, that before reaching such conclusions (often presented in casebooks $\left.{ }^{11}\right)$ - and after the presentation of arguments stemming from

\footnotetext{
8 On modern forms of slavery, see Mehra \& Shay (2016, pp. 453-468).

9 See Rorty (1993).

10 See McIntyre (2007) or Retter (2018, pp. 189-219).

${ }^{11}$ See, for example Allan \& Kraakman (2003, p. 3).
} 
a methodological approach that tries to shape legal knowledge on the basis of an analysis of the legal and philosophical literature, it is worth taking up a second methodological approach. We should analyze legal texts as well as court rulings to see whether such an approach can be more fruitful in finding an answer that would help to explain to businesses why they should care about human dignity and human rights.

In light of the difficulties that are not resolved by a study of the legal and philosophical literature, it is good to refer to international socio-political texts and to analyze them closely in the hope of finding a better answer. In its preamble, the Universal declaration of human rights states that 'recognition of the inherent dignity and of the equal and inalienable rights of all members of the human family is the foundation of freedom, justice and peace in the world' (United Nations, 1948). Some drafters understood that such a statement was not sufficient to secure recognition of the inherent dignity and rights of members of the human family ${ }^{12}$. Even though the Universal declaration states that 'the peoples of the United Nations have in the Charter reaffirmed their faith in fundamental human rights, in the dignity and worth of the human person', it adds at the same time that Member States have pledged themselves to the promotion of human rights and the recognition of human dignity, which is the foundation of freedom. That is why we read that the "common understanding of these rights and freedoms is of the greatest importance for the full realization of this pledge'. In other words, we can say that the very recognition of 'inherent dignity' did not end with the signing of the Universal declaration, but was the beginning of a long process of reaching a "common understanding'13.

In such a way, the Universal declaration followed the message that had been delivered in the UN charter, stating that 'the peoples of the United Nations determined to (...) reaffirm faith in fundamental human rights, in the dignity of the human person (...) have resolved to combine the efforts to accomplish this and other aims' (United Nations, 1945). By reading both at the same time, we can see that the UN charter and the Universal declaration set a goal that had to be achieved and did not merely state that it had been achieved already by the international adoption of these acts ${ }^{14}$. Such an approach may have seemed appropriate at that time these documents were created, when the world was still overshadowed by the collapse of belief in 'common understanding' that unites people across borders, nationalities, or cultures ${ }^{15}$. On the basis of the UN charter and Universal declaration, however, we can say that inherent human dignity is distinct from inalienable rights, that 'all human beings are born free and equal in dignity and rights' as art. 1 of the Universal declaration states and that both

12 For more on this subject, see Glendon (2001, p. 235).

13 See Glendon (2001, p. 236).

14 For more on this, see Glendon (2001, pp. 237-241).

15 On the collapse of the belief in 'common understanding', see Moyn (2010) or Rorty (1996). 
dignity and rights should be recognized. Such a perspective is present in another document. The International covenant on civil and political rights recognizes in the preamble that 'rights derive from the inherent dignity of the human person' (UN General Assembly, 1966). In other words, the ICCPR states, as do the previous texts, that there is human dignity and there are rights. However, the ICCPR views rights as being rooted in human dignity.

Interestingly, another document, the European convention for the protection of human rights and fundamental freedoms (Council of Europe, 1953) does not mention 'inherent human dignity', but mentions only 'Rights'. It should be noted, however, that it uses the term 'rights' with a capital ' $R$ '. This can be interpreted to mean that the rights intended to be protected are universal 'inalienable rights of all members of the human family', but, as the American philosopher Rorty (1993) would say, it could also mean that they are just rights of a higher status than other rights, although in general they are all culturally and historically developed. A defender of the universality of human rights would disagree with the second interpretation and would point to the language of the European convention and declare that because the convention considers the Universal declaration to aim at securing the 'universal and effective recognition and observance of the Rights' declared, then this means that it follows the position presented in the Universal declaration ${ }^{16}$. This position is that there are 'inalienable rights' common to all members of the human family. Such an interpretation could, of course, be questioned too and could be considered to be going too far. A critic might raise doubts about such a reading and argue that the European convention only presents its own interpretation of the meaning of the Universal declaration, and in fact the documents say two different things, or rather one says more than the other. In light of such doubts, one could say that according to the European convention, our goal should be to work toward a 'universal recognition', and that we should try to shape a common universal perception of 'Rights'. For the critic, this would not refer to inalienable rights, nor to inherent human dignity ${ }^{17}$.

It is worth noting that the American convention of human rights (Organization of American States, 1969) also does not refer to 'inherent human dignity' in its Preamble ${ }^{18}$. It mentions respect for the 'essential rights of man' and consid-

${ }^{16}$ Among the defenders of universality, one might mention Osiatyński (2009) or Symonides (2015, pp. 36-52).

17 It is important to add that while human dignity is not expressly mentioned in the European convention or the treaties of the European Union, the concept has reared its head in the case law of both the European Court of Human Rights and the European Court of Justice. It has been stated to be 'the very essence' of the convention. See O'Mahony (2012, p. 553).

18 As de Aguilar (2011, p. 5) says: "this proclamation is usually made in the preambles of the best known instruments, including the Helsinki Final Act, though, in some cases, in articles as well'. In the case of the American convention of human rights, the reference to dignity appears in art. 11.1 in the section on the right to privacy. 
ers them the basis for personal liberty and social justice. However, it explains in the preamble, and this seems crucial, that 'the essential rights of man are not derived from one's being a national of a certain state, but are based upon attributes of the human personality'. Because these 'essential rights', not just 'rights', are based upon certain attributes of the human personality, and of the human being, it seems that we may say that the approach in this act is the same as in the UN charter and the Universal declaration. There is something else apart from rights that must be recognized. There are certain 'attributes of human personality' which are real, which exist, and as in the ICCPR, are the basis for the rights mentioned in the American convention.

Yet another different approach is present in the African charter on human and people's rights (Organization of African Unity, 1981). Its preamble mentions dignity (among freedom, equality and justice) as an essential objective necessary for the 'achievement of the legitimate aspirations of the African people'. But dignity is mentioned here not as something that everyone has, but as something that must be achieved. In another part of the Preamble, we can read that the drafters of the African charter are conscious of the duty to achieve the liberation of the people who are still 'struggling for their dignity'19.

What picture can we draw from these few examples? When analyzing these treaties, one might ask what good comes from referring to human dignity? Some treaties mention 'inherent human dignity' as something that everyone has, or something that must be achieved by establishing certain conditions. In other treaties, human dignity is the basis for rights, or such rights are independent from it. This can be perceived as an inconsistency. The analysis raises further questions. Is human dignity something that must be recognized as a characteristic element of the life of every human being, or should we only try to believe that we have it, and that we can only reaffirm our faith in it? To answer these questions, we could analyze legal texts further, as well as courts judgements, but analyzing them would shed little new light on the problem. After completing such work on the ground of international texts and also by looking closely at international adjudications and the court decisions of various Supreme Courts or Constitutional Tribunals in Human dignity and judicial interpretation of human rights, Christopher McCrudden (2008, p. 675) concludes: 'what (...) emerges from an analysis of these (international) texts is significant differences in the ways in which human dignity has been incorporated into positive law. In many of the instruments, dignity is to be found in the preamble, whereas in others it is used to explicate particular rights. In some it is referred to as foundational in some sense; in others not. In some, human dignity is a right in itself (and in some systems, a particular privileged right), whilst, in other jurisdictions, it is not a right but a general principle'. These conclusions are also followed by other readers of international texts; some moderate, like Kateb (2011), Misztal (2013, pp. 1-23) or Sensen (2011, pp. 71-90), and others going

19 For more on that struggle, see Umozuruike (2007, pp. 179-190). 
far beyond legal analysis and presenting very radical views, such as Macklin (2003) or Pinker (2008).

\section{Problematic results}

In light of the above analysis of legal texts, the quest to look for a common understanding of human dignity and to defend its universal character seems problematic. It is worth adding that today analyzing other works also shows that it is not only difficult to find justifications for the universality of human dignity, but also to find contextual accounts that could be convincing ${ }^{20}$. Statements referring to history are controversial, as was pointed out when we analyzed Neuman. Of course, we could try to evaluate statements that 'the broad agreement to protect human rights came not from nature but from < history > - from the knowledge of the evil that human beings can do to one another' (Quataert, 2009, p. 54). But we cannot appreciate such statements when they are followed by others stating that "propelled by the genocidal wars, brutalities, and the Holocaust of mid-century, human rights principles offered alternatives to war and destruction in an agreed-on set of universal criteria for human dignity, fundamental justice, equality, and security' (Quataert, 2009, p. 304). We cannot agree with such a view because, first of all, on the basis of our reading of relevant international texts we see that there is no 'common understanding' of the character of 'human dignity'. Some texts mention the term, while others do not. Secondly, even if we do agree on the crucial role of referencing human dignity, then we face the problem of what rights are supported by reference to human dignity as a basis for their importance, and which are not to be prioritized.

What are also very problematic are statements such as the 'widespread commitment to dignity across different political systems and cultures was rooted in part in common beliefs from diverse religious traditions and customs and in part in the activist traditions defending autonomy, self-actualization, and independence - both personal and collective' (Quataert, 2009, p. 54). When we analyze international texts and different court decisions, it is hard to see this 'widespread commitment' across different political systems and cultures in the past as it is in the present, because very often dignity was and is understood differently in light of who is governing and what religion is dominant ${ }^{21}$. As McCrudden (2008, p. 698) argues, in different court judgements human dignity has been referred to on different occasions. At one point in time it was common to mention support for a particular right, while on another occasion, it was used to stress the importance of a previously neglected right and not the one supported before. What we see is that reference to human dignity is

20 As Giddens (1994, p. 20) says: 'it appears to many that we must now deal with an irremediably pluralistic universe of values, and indeed that the suspension of all value judgements, save for contextual and local ones, is the condition of cosmopolitanism'.

${ }^{21}$ For more on this subject, see Howard \& Donnelly (1986, pp. 801-817), May (2006, pp. 51-60) or Pollis (1982). 
used to support different rights, sometimes contradicting each other. It is due to the fact that the differing rights of Man often oppose each other: a woman's right of choice and the right to life of an unborn child, the right to die with dignity and the sanctity of life, the rights of children and the rights of parents, the rights of LGBT and the rights of freedom to practice religious beliefs ${ }^{22}$.

Of course, one could say that problems along the way should not weaken our belief that resolving them will be possible, and that this was actually the intention of the drafters of the Universal declaration, which 'was an agreement to establish a culture of activism to build the legal, institutional, and normative preconditions for the unfolding of human dignity in international political society' (Quataert, 2009, p. 54). This is the view of Quataert (2009, p. 304), who also says that the Universal declaration was 'rooted in struggle rather than in one universal, moral Truth' and it did not 'appeal to any universal theory of morality beyond the commitment to behave in a way sustained by human dignity. And it made no claim that human beings endowed with reason could arrive ultimately at one incontrovertible Truth. Rather, the declaration was an agreement on a code of behavior for members of the international community. It was silent about the metaphysical, moral, and religious reasons that might lie behind such a commitment, allowing each and every participant to have his and her own specific beliefs' (Quataert, 2009, p. 53).

\section{Conclusion}

The outcome of this analysis may not be satisfactory for businesses looking for clear explanations and rules for conduct. Should they be like the 'peoples of the United Nations', who at the same time declared the necessity to combine their efforts to reaffirm faith in human rights and human dignity among others? We should not forget that the process was not completed with the signing of the UN charter, but was recognized as one that will have to continue. We can say that the UN charter, like the Universal declaration, initiated the process rather than represented its culmination, 'that the Universal declaration expressed a set of aspirations rather than a readily attainable reality' (Hunt, 2007, p. 207). It presented several moral obligations for others to consider and not the one and only universal Truth to follow. For businesses that might be a promising answer in light of criticisms of their behavior (Wenar, 2017). They should feel welcome to have a say in how to develop the protection of human rights, especially when their own operations are at stake. But at the same time, with such an open approach, businesses should no longer use the explanation that their code of conduct is their internal affair, knowing the consequences they create not only for their shareholders but also for the larger society.

Solzhenitsyn rightly said that "no such thing as internal affairs remains on our crowded Earth. Mankind's salvation lies exclusively in everyone's making everything his business, in the people of the East being anything but in-

${ }^{22}$ For more on the clash of views on rights, see Glendon (1991). 
different to what is thought in the West, and in the people of the West being anything but indifferent to what happens in the East. Literature, one of the most sensitive and responsive tools of human existence, has been the first to pick up, adopt, and assimilate this sense of the growing unity of mankind' (Keys \& Burke, 2013, p. 493). In the same spirit, we could say that human rights are our business and it should be the business of businesses, not because there are some metaphysical or universal basis to ground them, but because our daily experience shows that our actions create consequences not only for us but also for others - sometimes horrible consequences. In light of that fact, we should apply a pragmatic approach, which looks to the consequences of our actions (Dewey, 1991a; Unger, 1998). It should not only be the interest of states who are involved in creating treaties and care for their implementation, but also the interest of businesses, which should agree to the Guiding principles on business and human rights. Agreeing to the Guiding principles should be however only the first step, which for businesses is not obvious, as evidenced by their push back during the process of creating the principles ${ }^{23}$. Another step should involve adjusting business conduct and internal codes of operation with the principles $^{24}$. And this is much more difficult when highly needed potential profits await. In light of business interests, Western corporations tend to push human rights issues to the side in the countries in which they invest or trade with as part of their activities ${ }^{25}$. They consider local governments as the ones that should resolve human rights, as accords with the private law actors-public law actors dichotomy, which divides the responsibility between them. They do not want anyone to intervene in their internal operations, as they fear a loss in their profit margins. But more and more research demonstrates that applying the pragmatic approach with a human face (Putnam, 1990) does not mean less but more profit (Sachs, 2006).

Thanks to the pragmatic approach we see reality in a much more complex way. This reality is shaped not only by nation-states but also by businesse ${ }^{26}$. Businesses are everyday a part of processes that curtail human rights when they trade with dictatorial regimes, pollute the environment, and do not care whether the goods they buy are produced in unhuman conditions. This situation impacts the way we are but also how we are - how we live, think, speak and communicate with others. In other words, one can say that businesses, like language, can bring us closer to each other and help in shaping the growing unity of mankind, or can humiliate us and undue the process. The pragmatic approach teaches us that businesses should start adjusting their conduct to be 'informed about oth-

${ }^{23}$ For more this subject, see Ruggie (2007, pp. 819-840).

${ }^{24}$ For more on this subject, see Campbell (2006, pp. 255-269), Webley \& Wernern (2008, pp. 405-415).

25 As an example, see the oil industry: Wenar (2017).

26 They impact the politics of a place, as well as social policy, economic policy, and the formalization of law. See Danielsen (2015, pp. 171-193). 
ers and search out the commonality of mankind and womankind' in a changing world (Menninger, 1976, p. 12). They should create value for people (Unger, 2007a). We should not 'tolerate too much more polarization and dehumanization. Nor can we pretend we are super-human and thus not subject to the same weaknesses and frailties as others' (Menninger, 1976, p. 12). Understanding our limitations can help us and our businesses to become more responsible for our actions. It can also help us to get involved in dialog about the needs of other people and to adjust the way we act.

Our position cannot be perfect, because the world in which we live is not perfect and we and our abilities to understand it and assess our actions within it are limited. We all make mistakes and we should not lock ourselves into the mode of thinking that we know best and that the issue is clear and already resolved. That has been the continued problem with the human rights regime. We should understand our own limitations and that we will never reach the final answer. But this situation is perfectly fine, so long as we have a dialogical, procedural basis for our conduct to rest on, including when we do business (Dewey, 1991b). One might ask: 'does that mean that we ought to have no standards beyond an affirmation of political liberty?' (Parker, 1994, p. 115), beyond an open dialog? The answer comes from Parker (1994, p. 115), who states the following: 'The point is to get out and take part in politics ourselves, not looking down from a <higher $>$ pedestal, but on the same level with all of the ordinary people. That this involves a risk is obvious. We are not sure of victory. We may not even be sure of our own convictions. Politics in democracy is an unsettling argument, an argument that never will be settled'.

Parkes responds that this is the politics that we have to learn. This is also the "politics" that should be present within the conduct of business conduct, which means that conduct should rest on communication with governments, civil society, workers, among others, who should be able to present critical opinions about its scope and consequences, and how those consequences affect others ${ }^{27}$. It should also rest on ongoing critical assessment of actions undertaken by businesses themselves. These are the very solutions that were presented long ago by Dewey (1991c) and recently by Unger (2007b) in light of the difficulties in finding the universal grounds to justify our actions and the law. History proves how important they are for business and business activities which can ruin people's health, the environment and business reputation, as was the case with BP (Kilanowski, 2017 pp. 47-57) or Volkswagen (Ewing, 2018). Instead of being divided, separated from each other on the basis of the sharp dichotomy between private law actors and -public law actors, not recognizing peoples' needs to protect their life and health, by our unquestioned convictions that what we do can only be good, we can become engaged in a dialog that will have the potential of building bridges instead of building walls. That dialog can lead to a better understanding of each other, a better understanding of human dig-

27 On the basis of such an approach Rhodes (2016) calls for the practice of 'democratic business ethics'. 
nity (Kilanowski, 2018), a better understanding and protection of human rights and can prevent further human rights violations caused by businesses ${ }^{28}$.

\section{References}

Allan, W.T., \& Kraakman, R. (2003). Commentaries and cases on the law of business organization. New York: Aspen Publishers.

Broome, J. (2000). Incommensurable values. In R. Crisp, \& B. Hooker (Eds.), Well-being and morality: essays in honour of James Griffin. Oxford: Clarendon Press.

Campbell, T. (2006). A human rights approach to developing voluntary codes of conduct for multinational corporations. Business Ethics Quarterly, 16(2). doi:10.5840/beq200616225.

Chang, R. (Ed.). (1997). Incommensurability, incomparability, and practical reason. Cambridge: Harvard University Press.

Council of Europe. (1953). European convention for the protection of human rights and fundamental freedoms. Retrieved 16.12.2019 from http://wwwl.umn. edu.

Danielsen, D. (2015). Corporate power and instrumental states: toward a critical reassessment of the role of firms, states, and regulation in global governance. In B. Stark (Ed.), International law and its discontents: confronting crises. Cambridge: Cambridge University Press.

de Aguilar, J.P.A. (2011). Human dignity according to international instruments on human rights. Revista Electrónica de Estudios Internacionales, 22.

Dewey J. (1991b). Liberalism and social action. In J.A. Boydston (Ed.), The later works: 1925-1953. Carbondale: Southern Illinois University Press.

Dewey, J. (1991a). Democracy is radical. In J.A. Boydston (Ed.), The later works: 1925-1953. Carbondale: Southern Illinois University Press.

Dewey, J. (1991c). Public and its problems. In J.A. Boydston (Ed.), The later works: 1925-1953. Carbondale: Southern Illinois University Press.

Dupré, C. (2015). The age of dignity: human rights and constitutionalism in Europe. London: Hart Publishing.

Ewing, J. (2018). Volkswagen's efforts to stop scandals needs more work: report says. New York Times, 27.08.2018.

Giddens, A. (1994). Beyond left and right, the future of radical politics. Stanford: Stanford University Press.

Gilabert, P. (2018). Human dignity and human rights. Oxford: Oxford University Press.

Glendon, M.A. (1991). Rights talk: the impoverishment of political discourse. New York: Free Press.

Glendon, M.A. (2001). A world made new: Eleanor Roosevelt and the universal declaration of human rights. New York: Random House.

${ }^{28}$ See for example the Kiobel Case (Kiobel v. Royal Dutch Petroleum, 2013). 
Habermas, J. (2010). The concept of human dignity and the realistic utopia of human rights. Metaphilosophy, 4l(4). doi:10.1111/j.1467-9973.2010.01648.x.

Howard, R.E., \& Donnelly, J. (1986). Human dignity, human rights, and political regimes. American Political Science Review, 80(3). doi:10.2307/1960539.

Hunt, L. (2007). Inventing human rights: a history. New York: W.W. Norton \& Company.

Huntington, S.P. (2011). On clash of civilizations and the remaking of world order. New York: Simon \& Schuster.

Kateb, G. (2011). Human dignity. Cambridge: Belknap Press.

Kennedy, D. (2004). The dark sides of virtue: reassessing international humanitarianism. Princeton-Oxford: Princeton University Press.

Keys, B., \& Burke, R. (2013). Human rights. In R.H. Immerman, \& P. Goedd (Eds.), The Oxford handbook of the cold war. Oxford: Oxford University Press. doi:10.1093/oxfordhb/9780199236961.013.0028.

Kilanowski, M. (2017). Deep capture: the hidden role of psychology, ideology and corporate law. Ekonomia i Prawo. Economics and Law, 16(1). doi:10.12775/ eip.2017.004.

Kilanowski, M. (2018). W obronie ludzkiej godności i solidarności: Erich Fromm i Isaiah Berlin ku nowym filozoficznym podstawom dla państwa i prawa. Toruń: UMK.

Kiobel v. Royal Dutch Petroleum Co., 133 S.Ct. 1659 (2013).

Kymlicka, W. (2010). The rise and fall of multiculturalism? New debates on inclusion and accommodation in diverse societies. International Social Science Journal, 61(199). doi:10.1111/j.1468-2451.2010.01750.x.

Macklin, R. (2003). Dignity is a useless concept. British Medical Journal, 327(7429). doi:10.1136/bmj.327.7429.1419.

May, J.D. (2006). Human dignity, human rights, and religious pluralism: Buddhist and Christian perspectives. Buddhist-Christian Studies, 26(1). doi:10.1353/bcs.2006.0016.

McCrudden, C. (2008). Human dignity and judicial interpretation of human rights. European Journal of International Law, 19(4). doi:10.1093/ejil/chn043.

McCrudden, C. (Ed.). (2012). Understanding human dignity. Oxford: Oxford University Press.

McIntyre, A. (2007). After virtue: a study in moral theory. Notre Dame: University of Notre Dame Press.

Mehra, A., \& Shay, K. (2016). Corporate responsibility and accountability for modern forms of slavery. Journal of International Criminal Justice, 14(2). doi:10.1093/jicj/mqw023.

Menninger, W. W. (1976). Speech for the conference on human dignity and American democracy. In E.E. Grollmes (Ed.), A report on the Bicentennial Conference on human dignity and American democracy. Saint Louis: Saint Louis University.

Misztal, B.A. (2013). The idea of dignity: its modern significance. European Journal of Social Theory, 16(1). doi:10.1177/1368431012449237. 
Moyn, S. (2010). The last utopia: human rights in history. Cambridge: Harvard University Press.

Neuman, G. (2000). Human dignity in United States constitutional law. In D. Simon, \& M. Weiss (Eds.). Zur Autonomie des Individuums. Baden-Baden: Nomos Verlagsgesellschaft.

O'Mahony, C. (2012). There is no such thing as a right to dignity. International Journal of Constitutional Law, 10(2). doi:10.1093/icon/mos010.

Organization of African Unity. (1981). African charter on human and people's rights. Retrieved 16.12.2019 from http://wwwl.umn.edu.

Organization of American States. (1969). American convention of human rights. Retrieved 16.12.2019 from https://www.cidh.oas.org.

Osiatyński, W. (2009). Human rights and their limits. Cambridge: Cambridge University Press.

Parker, R. (1994). Here, the people rule: a constitutional populist manifesto. Cambridge: Harvard University Press.

Pearce, W.B., \& Littlejohn, S.W. (1997). Moral conflict: when social worlds collide. Thousand Oaks: Sage Publications.

Pinker, S. (2008). The stupidity of dignity. The New Republic, 28.05.2008.

Pollis, A. (1982). Liberal, socialist and third world perspectives on human rights. In A. Pollis, \& P. Schwab (Eds.), Towards a human rights framework. New York: Praeger.

Putnam, H. (Ed.). (1990). Realism with a human face. Cambridge: Harvard University Press.

Quataert, J.H. (2009). Advocating dignity, human rights mobilizations in global politics. Philadelphia: University of Pennsylvania Press.

Retter, M.D. (2018). The road not taken: On MacIntyre's human rights skepticism. The American Journal of Jurisprudence, 63(2). doi:10.1093/ajj/auy012.

Rhodes, C. (2016). Democratic business ethics: Volkswagen's emissions scandal and the disruption of corporate sovereignty. Organization Studies, 37(10). doi:10.1177/0170840616641984.

Rorty, R. (1993). Human rights, rationality, and sentimentality. In S. Shute, \& S. Hurley (Eds.), On human rights. New York: Basic Books.

Rorty, R. (1996). On moral obligation, truth, and common sense. In J. Niżnik, \& J.T. Sanders (Eds.), Debating the state of philosophy: Habermas, Rorty, Kotakowski. Westport: Praeger.

Ruggie, J.G. (2007). Business and human rights: the evolving international agenda. The American Journal of International Law, 101(4).

Sachs, J. (2006). The end of poverty. New York: Penguin Books.

Sandel, M. (2013). What money can't buy: the moral limits of markets. New York: Farrar, Straus and Giroux.

Sensen, O. (2011). Human dignity in historical perspective: the contemporary and traditional paradigms. European Journal of Political Theory, 10(1). doi:10.1177/1474885110386006. 
Symonides, J. (2015). Uniwersalizm a relatywizm kulturowy: różnorodność kulturowa i regionalizm w prawach człowieka. In J. Jaskiernia (ed.), Uniwersalny i regionalny wymiar ochrony praw cztowieka: nowe wyzwania, nowe rozwiązania. Warszawa: Wydawnictwo Sejmowe.

Turner, B. (2006). Vulnerability and human rights. University Park: Pennsylvania State University Press.

Umozuruike, U.O. (2007). The African charter on human and peoples' rights: suggestions for more effectiveness. Annual Survey of International and Comparative Law, 13(1).

UN General Assembly. (1966). International covenant on civil and political rights. Retrieved 16.12.2019 from https://www.ohchr.org.

Unger, R.M. (1998). Democracy realized: the progressive alternative. New York: Verso.

Unger, R.M. (2007a). Free trade reimagined: the world division of labor and the method of economics. Princeton: Princeton University Press.

Unger, R.M. (2007b). The self awakened: pragmatism unbound. Cambridge: Harvard University Press.

United Nations. (1945). Charter of the United Nations. Retrieved 16.12.2019 from https://www.un.org.

United Nations. (1948). Universal declaration of human rights. Retrieved 16.12.2019 from https: / /www.un.org.

United Nations. (2011). Guiding principles on business and human rights. Retrieved 16.12.2019 from https://www.ohchr.org.

Waldron, J. (2012). Dignity, rank, and rights. Oxford: Oxford University Press.

Webley, S., \& Wernern, A. (2008). Corporate codes of ethics: necessary but not sufficient. Business Ethics: A European Review, 17(4). doi:10.1111/j.1467-8608.2008.00543.x.

Wenar, L. (2017). Blood oil: tyrants, violence, and the rules that run the world. Oxford: Oxford University Press.

\section{Acknowledgements}

Author contributions: author has given an approval to the final version of the article.

Funding: this research was funded by the author's own resources.

Note: the results of this study were presented at conference Karta Praw Podstawowych i jej znaczenie dla polskiego systemu prawnego (May 10-11, 2019, Warsaw, Poland) 
